\section{Kidney \\ Blood Pressure Research}

\title{
The Enhancement of Cx45 Expression and Function in Renal Interlobar Artery of Spontaneously Hypertensive Rats at Different Age
}

\author{
Li Lia,b Wen Zhang ${ }^{a}$ Wen Yan Shia,c Ke-Tao Ma ${ }^{a, b}$ Lei Zhao ${ }^{a, b} \quad$ Yang Wang ${ }^{a}$ \\ Liang Zhang ${ }^{a, b} \quad$ Xin-ZHi Li,b He Zhu ${ }^{a, b}$ Zhong-Shuang Zhang ${ }^{a, b} \quad$ Wei-Dong Liu ${ }^{a}$ \\ Jun-Qiang $\mathrm{Si}^{\mathrm{a}, \mathrm{b}, \mathrm{c}, \mathrm{d}}$
}

aDepartment of Physiology, and ${ }^{\mathrm{b} T}$ The Key Laboratory of Xinjiang Endemic and Ethnic Diseases, Medical College of Shihezi University, Shihezi 832002; 'Department of Neurobiology, Tongji Medical College, Huazhong University of Science and Technology, Wuhan 430030; 'Department of Physiology, Wuhan University School of Basic Medical Sciences, Wuhan 430070, China

\section{Key Words}

Connexin • Gapjunction • Renal interlobar artery • Vascular smooth muscle cell • Spontaneously hypertensive rats $\bullet$ Vasoconstriction

\begin{abstract}
Background/Aims: This study was designed to investigate the expression and function of gap junction protein connexin $45(\mathrm{C} \times 45)$ in renal interlobar artery (RIA) of spontaneously hypertensive rats (SHR), and the association between hypertension and enhanced vasoconstrictive response in SHR. Methods: Western blot analysis and pressure myography were used to examine the differences in expression and function of $\mathrm{Cx} 45$ in vascular smooth muscle cells (VSMCs) of RIA between SHR and normotensive Wistar-Kyoto (WKY) rats. Results: Our results demonstrated that 1 ) whole-cell patch clamp measurements showed that the membrane capacitance and conductance of in-situ RIA VSMCs of SHR were significantly greater than those of WKY rats $(p<0.05, n=6)$, suggesting that the coupling of gap junction between VSMCS of RIA was enhanced in SHR; 2 ) the $\mathrm{KCl}$ or phenylephrine (PE)-stimulated RIA constriction was more pronounced in SHR than that in WKY rats $(p<0.05, n=10)$. After applying a gap junction inhibitor $18 \beta$-glycyrrhetintic acid (18ß-GA), the inhibitory effect of $18 \beta-\mathrm{GA}$ on $\mathrm{KCl}$ or PE-induced vasoconstriction was greater in SHR $(p<0.05, \mathrm{n}=10)$; and 3$)$ the expression of $\mathrm{Cx} 45$ in RIA of SHR was greater than that in WKY rats $(p<0.05, \mathrm{n}=3)$ at 4 ,
\end{abstract}

L. Li and W. Zhang contributed equally to this work and therefore share first authorship.

Prof Jun-qiang $\mathrm{Si}$

KARGER 125\%
Department of Physiology, and The Key Laboratory of Xinjiang Endemic and Ethnic Diseases, Medical College of Shihezi University, Shihezi 832002 (China) Tel. +86-993-205-7555, Fax +86-993-205-7555, E-Mail sijunqiang11@hotmail.com 


\section{Kidney Blood Pressure Research}

Kidney Blood Press Res 2015;40:52-65

\begin{tabular}{l|l}
\hline DOI: 10.1159/000368482 & (c) 2015 S. Karger AG, Basel
\end{tabular}

Published onine: Fedruary 20, 2015

www.karger.com/kbr

Li/Zhang/Shi/Ma/Zhao/Wang/Zhang/Li/Zhu/Zhang/Liu/Si: Enhanced Cx45 Expression and Function in Spontaneously Hypertensive Rats

12 and 48 wks of age. Conclusions: The hypertension-induced elevation of Cx45 may affect communication between VSMCs and coupling between VSMCs and endothelium, which results in an increased vasoconstrictive response in renal artery and might contribute to the development of hypertension.

Copyright @ 2015 S. Karger AG, Basel

\section{Introduction}

Hypertension can cause damage in heart, brain, kidney and vascular dysfunction, and is an important risk factor for the rapid progression of renal failure. Cross transplantation of kidneys between spontaneously hypertensive rats (SHR) and normotensive rats leads to development of hypertension in normotensive rats and normalization of the blood pressure (BP) in SHR [1-3]. Renal circulation plays a crucial role in the regulation of arterial blood pressure. Changes in structure and function of renal vasculature are associated with the development of hypertension [4]. Afferent arterioles originate from interlobular arteries and deliver blood to the glomeruli [4]. Cells in renal arterioles are coupled with each other and express several connexins (Cxs) in a cell-specific pattern [5]. Four isoforms of the Cxs, Cx37, $\mathrm{Cx} 40, \mathrm{Cx} 43$, and $\mathrm{Cx} 45$ are expressed in renal vasculature of mice, rats, rabbits and humans, with predominant expression of $\mathrm{Cx} 40$ in endothelial cells (ECs) and $\mathrm{Cx} 45$ in vascular smooth muscle cells (VSMCs) $[4,6,7]$. These Cxs play important roles in regulation of secretion of renin ( $\mathrm{Cx} 40 / \mathrm{Cx} 43 / \mathrm{Cx} 45)$, signaling in juxtaglomerular apparatus (JGA)(Cx40/Cx45), regulation of renal blood flow (Cx40), and coupling of VSMCs and ECs (Cx40/Cx43) [6]. The interactions between the different isoforms of $\mathrm{Cxs}$ form homomeric and heteromeric connexons [5]. Heterotypic channels are formed between $\mathrm{Cx} 45$ and $\mathrm{Cx} 40 / \mathrm{Cx} 43$ in several cell types and each combination has unique feature in the mesangium and likely the granular cells $[6,8]$. Compared to most membrane proteins, the turnover rate of Cxs is fast (halflife of 1.5-5 hrs) [9], which implies that modulation of the Cx degradation rate might be an important mechanism for controlling the level of gap junction to regulate intercellular communication under physiological and pathopysiological conditions [10]. The regulation of gap junction assembly and turnover can be modulated by several proteins that interact with Cxs, such as structural proteins (e.g. zona occludens-1 [ZO-1] and microtubules), protein kinase and phosphatases [11]. Among them, ZO-1 participates in the regulation of gap junction assembly by facilitating the coupling of connexon with the actin cytoskeleton [12]. Thus, the Cxs-ZO-1 interaction may be an important regulator of gap junction formation and maintenance on the membrane.

The changes in expression and function of Cxs in renal vasculature are associated with the development of vascular diseases, including hypertension, hyperreninemia, tatherosclerosis, and restenosis [4]. Cxs in kidney likely exert an essential function in renal autoregulatory mechanisms (tubuloglomerular feedback) and in vasomotor responses [5]. In renal circulation, the role of $\mathrm{Cx} 40$ in modulating renin secretion and blood pressure is well documented. Deletion of $\mathrm{Cx} 40$ results in hyperplasia of renin-producing cells in kidney, hyperreninemia, and hypertension $[13,14]$. Further, $\mathrm{Cx} 45$ can functionally replace $\mathrm{Cx} 40$ for regulation of renin secretion and blood pressure when $\mathrm{Cx} 45$ was knocked into the genome of Cx40 knock out mice [15], indicating the two isoforms may be functionally interchangeable [15].

Gap junction can also affect the vasomotor activity by regulating vasomotor tone [16, 17]. Vascular conductive responses coordinate microcirculatory control in vascular beds, and these responses are the consequence of direct intercellular communication between cells on the vascular wall [18-20]. As a consequence of intercellular communication, local vascular constrictive or dilatory stimulation can be propagated along the length of the 


\section{Kidney Blood Pressure Research}

Kidney Blood Press Res 2015;40:52-65

\begin{tabular}{l|l}
\hline DOI: $10.1159 / 000368482$ & (c) 2015 S. Karger AG, Basel
\end{tabular}

Publisned oninne: February 20, 2015

www.karger.com/kbr

vascular wall, leading to constrictive or dilatory responses at sites several millimeters from the stimulation site [21-23]. Intercellular communication travels through gap junctions on the cell membrane..

An increased communication between cells has been demonstrated in the renal microvasculature of SHR. An increase in activity of the tubuloglomerular feedback mechanism [24-26] has been shown in young SHR, resulting in renal vasoconstriction and sodium retention [27]. The increased tubuloglomerular feedback response in SHR is associated with a stronger nephron-nephron coupling in SHR [28].

It is known that the structure and function of blood vessels change during aging. However, the expression of gap junction proteins on renal blood vessels at different ages, especially during the development of hypertension, has not been studied. The goal of the present study is to test whether an increase in gap junction communication is associated with the increase in Cx45 expression on renal blood vessels of SHR during the development of hypertension. We used whole-cell patch clamping technique, pressure myography and Western blot analysis to study the differences in function and expression of gap junctions between VSMCs of renal interlobar artery (RIA) of SHR and control normotensive WistarKyoto (WKY) rats at different ages.

\section{Materials and Methods}

\section{Animals}

4, 12 and 48 wks old male SHR and WKY rats were used in this study. All protocols were approved by the Institutional Animal Care and Use Committee (IACUC) at the Medical College of Shihezi University and were consistent with the Guidelines for the Care and Use of Laboratory Animals published by the US National Institutes of Health (Public Health Service Policy on Humane Care and Use of Animals, DHEW Publication No. 96-01, PHS Policy revised in 2002). BP was measured by the tail cuff method. To collect RIA, rats were anesthetized with an injection (i.m., $1 \mathrm{ml} / \mathrm{kg}$ ) of a mixture of ketamine/xylazine/acepromazine (500/20/10 $\mathrm{mg}$ in $8.5 \mathrm{ml} \mathrm{H}_{2} \mathrm{O}$ ) and subsequently euthanized. RIA was dissected out from the upper renal artery, and surrounding connective and adipose tissue were removed for whole-cell patch clamp recording, pressure myographic measurement, and Western blot analysis.

\section{Whole-cell patch clamp recording}

RIA ( $\sim 0.4 \mathrm{~mm}$ in length, $200 \mathrm{~mm}$ in diameter) was placed on a glass-bottom petri dish which was filled with oxygen saturated external solution containing (in $\mathrm{mM}$ ): $\mathrm{NaCl} 138, \mathrm{KCl} 5, \mathrm{CaCl}_{2} 21.6, \mathrm{MgCl}_{2} 21.2$, Na-HEPES 5.0, HEPES 6.0 and glucose 7.5. RIA segments were treated with external solution containing collagenase $\mathrm{A}(1 \mathrm{mg} / \mathrm{ml})$ for $15 \mathrm{~min}$ at $37^{\circ} \mathrm{C}$. After washed out collagenase with external solution twice the segments were further cleaned to remove adventitial tissue. RIA segments were anchored to the bottom by placing platinum strips on each end. The petri dish was then placed onto the stage of an inverted microscope equipped with micromanipulators. The segments were continuously perfused with external solution $(0.2$ $\mathrm{ml} / \mathrm{min}$ ) at room temperature.

To isolate VSMCs from RIAs, RIAs were incubated in a low- $\mathrm{Ca}^{2+}$ solution for 20 min containing (in $\mathrm{mM}$ ): $\mathrm{NaCl} 142, \mathrm{KCl} 5, \mathrm{CaCl}_{2} 0.05, \mathrm{MgCl}_{2}$ 1.0, Na-HEPES 4.0, HEPES 5.0 and glucose 7.5, and cut into 1 mm segments and digested with low-Ca ${ }^{2+}$ solution containing papain $(1.5 \mathrm{mg} / \mathrm{ml})$, collagenase $\mathrm{A}(2 \mathrm{mg} / \mathrm{ml})$, bovine serum albumin (BSA, $3.75 \mathrm{mg} / \mathrm{ml})$ and DL-dithiothreitol $(0.3 \mathrm{mg} / \mathrm{ml})$ for $20-25 \mathrm{~min}$ at $37^{\circ} \mathrm{C}$. After centrifuging $(67 \mathrm{x}$ $\mathrm{g}$ for $5 \mathrm{~min}$ ) and replacing the supernatant with enzyme-free low-Ca ${ }^{2+}$ solution three times, the preparation was triturated with a Pasteur pipette. The cell-rich suspension was transferred to a petri dish with a poly-Llysine-coated coverslip at the bottom. After the dispersed cells attached to the coverslip, the dish was placed onto the stage of an inverted microscope and perfused with extracellular solution for whole-cell recording.

Conventional whole-cell patch clamp recording was performed using an Axon 700B amplifier (Axon Instruments, Union City, CA, USA) as described previously [29]. The pipette had a resistance of approximately $5 \mathrm{M} \Omega$ after being filled with internal solution containing (mM): K-gluconate 130, $\mathrm{NaCl} 10, \mathrm{CaCl}_{2} 2, \mathrm{MgCl}_{2}$ 1.2, HEPES 10, ethylene glycol-bis [ $\beta$-aminoethylether] $\mathrm{N}, \mathrm{N}^{\prime}, \mathrm{N}^{\prime}$-tetraacetic acid 5 and glucose 7.5. The seal 


\section{Kidney \\ Blood Pressure Research}

Kidney Blood Press Res 2015;40:52-65

\begin{tabular}{l|l}
\hline DOI: $10.1159 / 000368482$ & (c) 2015 S. Karger AG, Basel
\end{tabular}

Publisned oninne: February 20, 2015

www.karger.com/kbr

Li/Zhang/Shi/Ma/Zhao/Wang/Zhang/Li/Zhu/Zhang/Liu/Si: Enhanced Cx45 Expression and Function in Spontaneously Hypertensive Rats

resistance usually reached 1-20 G $\Omega$ before rupture of the membrane. The membrane current or voltage signal were filtered at $10 \mathrm{kHz}$ and recorded on a PC equipped with a Digidata $1440 \mathrm{~A}$ AD-interface and pClamp 10.2 software (Axon Instruments, Union City, CA, USA) at a sampling interval of 10, 20 or $100 \mathrm{~ms}$. A Minidigi digitizer and Axoscope 10.2 software (Axon Instruments) were used to perform gap-free recording at a sampling interval of $50 \mathrm{~ms}$.

The transient current over the membrane input capacitance $\left(C_{\text {input }}\right)$ was uncompensated to calculate the access resistance $(R a)$ and the membrane parameters on-line or off-line. The off-line calculation was performed with an exponential fit to the capacitive current transients by employing commonly used equations. The $C_{\text {input }}$ values for in-situ cells were calculated according to $C=Q / V$, in which the charge $(Q)$ was obtained by a four-term exponential fit to the current transient elicited by a voltage step. The voltage clamping error introduced by the current ( $I$ ) passing the Ra was corrected according to the equation $V \mathrm{~m}=V_{\mathrm{c}} /$ Ira (in which $V \mathrm{~m}$ is the actual clamping membrane voltage and $V c$ is the apparent command voltage).

\section{Pressure myographic measurement}

RIA segments were placed in an $4^{\circ} \mathrm{C}$ oxygen saturation physiological solution containing (in mM): $\mathrm{NaCl}$ 118.9, $\mathrm{KCl} 4.7, \mathrm{MgSO}_{4} 1.2, \mathrm{KH}_{2} \mathrm{PO}_{4} 1.2, \mathrm{CaCl}_{2} 2.5, \mathrm{NaHCO}_{3} 25$, and glucose 5.5. RIA segment was tied to a glass tube using 12-0 nylon monofilament sutures, and placed in a microvascular chamber (Pressure Myograph System, DMT, Denmark) [30]. The chamber was perfused with physiological solution (pH 7.4, bubbled with $95 \% \mathrm{O}_{2}$ and $5 \% \mathrm{CO}_{2}$ ) and heated to $37^{\circ} \mathrm{C}$. RIA segment was pressurized to a constant transmural pressure of $60 \mathrm{mmHg}$. The diameter was continuously determined using a video dimension analyzer and recorded using the DMT Vessel Acquisition Suite. RIA segment was treated with progressively increasing doses of PE $(0.01-30 \mu \mathrm{M})$ and following by increasing doses of $\mathrm{KCl}(10-100 \mathrm{mM})$. The results were evaluated according to the changes in vascular diameter recorded on the DMT [30].

\section{Western blot analysis}

RIA was homogenized in RIPA buffer (at a ratio of $100 \mathrm{mg}$ of tissue to $200 \mu \mathrm{l}$ of RIPA buffer) with addition of freshly prepared protease inhibitor cocktail. Tissue homogenate was incubated at $4^{\circ} \mathrm{C}$ for $30 \mathrm{~min}$ and centrifuged at $12,000 \mathrm{xg}$ at $4^{\circ} \mathrm{C}$ for $15 \mathrm{~min}$. The supernatant was collected, and the protein concentration was determined. Protein aliquots $(40 \mu \mathrm{g})$ were subjected to $4-15 \%$ Tris-glycine denaturing gradient gel electrophoresis and then transferred to a NC membrane. The membrane was hybridized with specific primary antibodies against $\mathrm{Cx} 45$ at $4^{\circ} \mathrm{C}$ overnight. The membrane was then incubated with a fluoresceinconjugated secondary antibody at room temperature for $1 \mathrm{hr}$. Immunoreactive bands were detected using the ECL chemiluminescence reagent (GE Healthcare Bio-Sciences AB, Uppsala, Sweden). Membrane was stripped and re-labeled with $\beta$-actin antibody as an internal control. The intensity of protein bands was analyzed using a Quantity One software (Bio-Rad, Hercules, CA, USA) [31].

\section{Reagents}

Primary antibodies and the horseradish peroxidase-conjugated secondary antibody were obtained from Santa Cruz Biotechnology(Dallas, Texas USA). The BCA protein assay kit was obtained from Pierce(Thermo Fisher Scientific Inc. Rockford, IL USA). RIPA buffer, PE and 18ß-GA were purchased from Sigma( Sigma-Aldrich China, Inc. Shanghai, PRC). 18ß-GA was dissolved in dimethyl sulfoxide (DMSO) as a stock solution before being further diluted with external solution to achieve the final concentration. The final DMSO concentration in solution was $\leq 0.1 \%$, which had no detectable effect on vasomotor activity.

\section{Statistical analysis}

SHR and WKY rats were age matched to minimize individual differences. Results are expressed as means \pm SEM. Statistical analysis was performed using the SPSS (Statistical Package for the Social Sciences) 17.0 statistical software package. The primary statistical tests was performed by 2-tailed paired or unpaired Student's t test, or 1 and 2-way ANOVA, if not stated otherwise. When the overall $\mathrm{F}$ test result of analysis of variance was significant, a multiple comparison Tukey test was applied. Student's t-test was used for comparisons between two means. The differences were considered significant when the $\mathrm{p}$ values were $<0.05$. 


\section{Kidney \\ Blood Pressure Research}

\section{Results}

\section{Basal parameters}

The body weight \pm SEM of SHR $(227.2 \pm 4.5 \mathrm{~g})$ and WKY rats $(242.1 \pm 7.3 \mathrm{~g})$ were not different through 4 48 weeks of age. The systolic pressure of SHR was significantly higher than that of WKY rats at 12 and 48 weeks of age (Table 1). The outer diameter of RIA of SHR was significantly less than that of WKY rats at 4,12 and 48 weeks of age (Table 2).

\section{Cx45 expression increased in the RIA of SHR}

It has been reported that Cx45 is expressed in VSMCs of small arterioles and large conducting vessels (A. gracilis, femoral, and mesenteric arteries), but not in ECs [32]. In the current study, we demonstrated that, $\mathrm{Cx} 45$ was highly expressed in VSMCs of RIA and cardiac muscle of SHR and WKY rats. Further, a significant up-regulation of $\mathrm{Cx} 45$ expression was observed in both 12-wk-old SHR and WKY rats compared to that of 4-wk-old and 48-wk-old SHR and WKY rats (data not shown). A marked increase of $\mathrm{Cx} 45$ protein was also detected in the RIA and cardiac muscle of SHR compared to that of age-matched WKY rats (Figure 1).

Membrane properties of VSMCs in RIA of SHR and WKY rats

Whole-cell recordings on in-situ or dispersed RIA VSMCs of SHR and WKY rats were shown in Figure 2. Step and ramp voltage commands from a holding potential of $-40 \mathrm{mV}$ were applied to measure the membrane properties. The current transients showed a time course that fit poorly to a single-term exponential function in the insitu VSMCs of SHR and WKY rats (Figure 2A). However, these current transients fit well to a four-term exponential function (not shown), indicating a multiple source in charging the circuit or an electrical coupling of multiple cells in the vessel. Treatment with gap junction inhibitor 18 $\beta$-glycyrrhetintic acid
(C) 2015 S. Karger AG, Basel

Table 1. Blood pressure of SHR and WKY rats at 4,12 and 48

Table 2. Size of renal interlobar artery (RIA) of SHR and WKY

$\begin{array}{llll}48 & 8 & 363.2 \pm 6.8 & 312.3 \pm 5.4^{*}\end{array}$

\begin{tabular}{cc} 
WKY & SHR \\
$356.7 \pm 6.5$ & $308.6 \pm 5.6^{*}$ \\
$362.5 \pm 5.7$ & $311.4 \pm 7.2^{*}$ \\
$363.2 \pm 6.8$ & $312.3 \pm 5.4^{*}$ \\
\hline M. $^{*} p<0.01$, compared to the
\end{tabular}

Results are means \pm SEM. ${ }^{*} p<0.01$, compared to the same age WKY

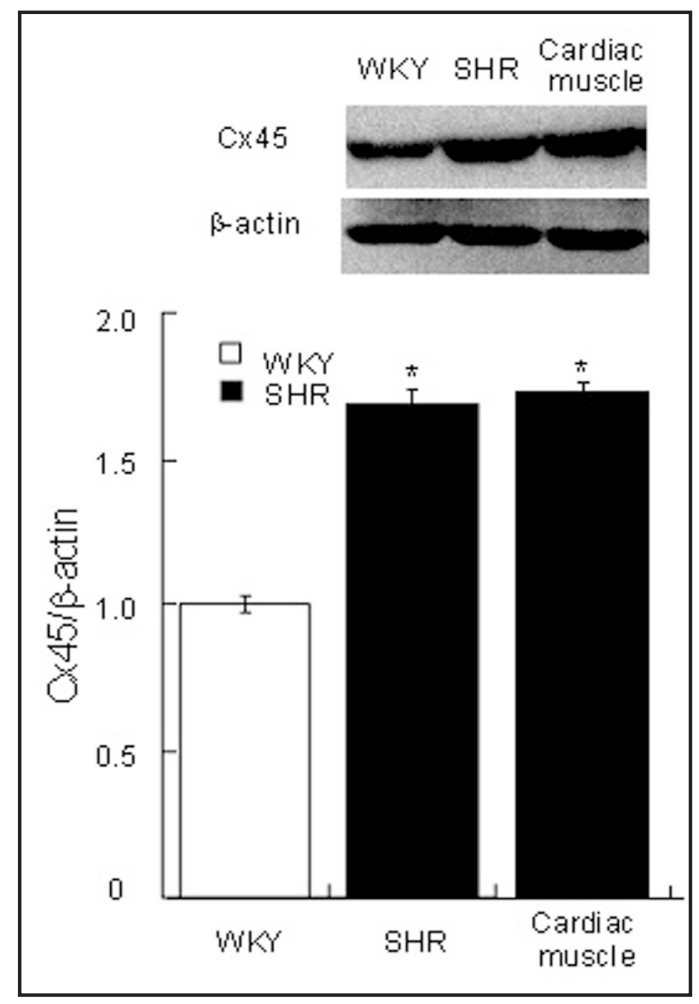

Fig. 1. Western blot analysis showed $\mathrm{Cx} 45$ protein levels in RIA of 12-wk old SHR and WKY rats. Results are means \pm SEM, $n=6 /$ group. ${ }^{*} \mathrm{p}<0.05$, compared to WKY rats. Cardiac muscle was used as a positive control. 


\section{Kidney \\ Blood Pressure \\ Research}

Kidney Blood Press Res 2015;40:52-65

\begin{tabular}{l|l}
\hline DOI: $10.1159 / 000368482$ & (C) 2015 S. Karger AG, Basel
\end{tabular}

Publisned onitne: February 20, 2015

www.karger.com/kbr

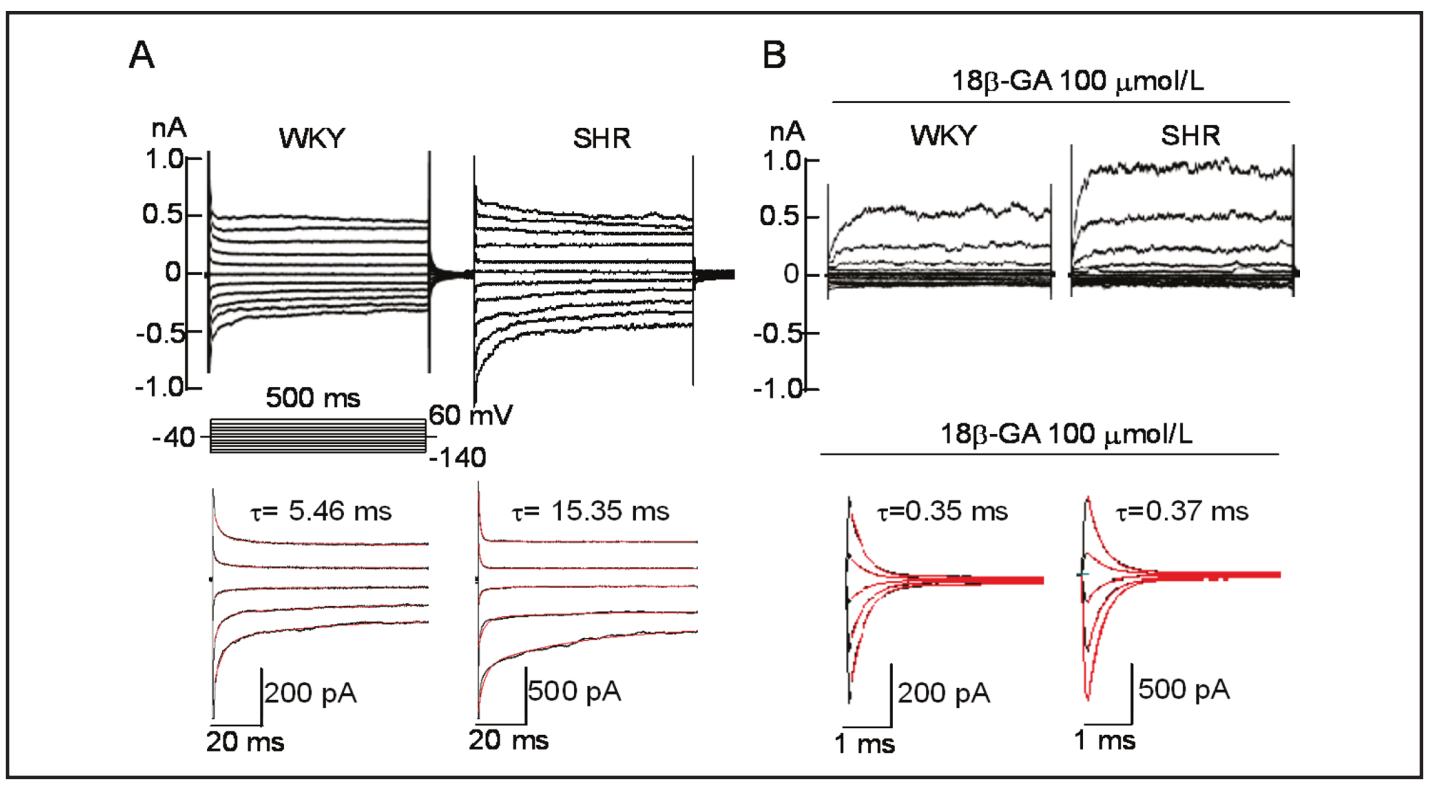

Fig. 2. The electrical coupling of in-situ VSMCs in renal interlobar artery (RIA) segment of 12-wk old SHR and WKY rats. A) Whole-cell current traces induced by voltage steps from the holding potential at $-40 \mathrm{mV}$ in $20 \mathrm{mV}$ increments on in-situ RIA VSMCs of WKY rats and SHR. Expanded time scale of the initial part of currents (red tracing) showed that a single term exponential function fitted poorly $(\mathrm{r}<0.90)$ with the transient current (black thin line). B) Gap junction inhibitor $18 \beta-\mathrm{GA}(100 \mu \mathrm{M})$ caused significant reduction in the steady-state current (Iss). Expanded time scale of the initial part of currents (red tracing) showed that a single term exponential function fitted well ( $r>0.98$ ) after the treatment with $18 \beta-G A$. " $\tau$ " is the time constant of the bottom trace.

$(18 \beta-G A)$ caused significant reduction in the steady-state current (Figure 2B). Expanded time scale of the initial part of currents showed that a single term exponential function fitted well after the treatment with $18 \beta-\mathrm{GA}$.

The results of $R_{\text {input }}, G_{\text {input }}, C_{\text {input }}$ and $\tau$ values of in-situ and dispersed RIA VSMCs are summarized in Table 3. The $R_{\text {input }}$ value of in-situ VSMCs in SHR rats was lower than that of WKY rats, but the $G_{\text {input' }} C_{\text {input }}$ and $\tau$ values of in-situ VSMCs in SHR rats were greater than those of VSMCs in WKY rats, respectively. The $R_{\text {input }}$ values of the dispersed VSMCs of SHR and WKY rats were 28 and 8 times greater than those of the in-situ VSMCs of SHR and WKY rats, respectively. The $G_{\text {input }} C_{\text {input }}$ and $\tau$ values of in-situ VSMCs were 20, 32, 41 and 9, 17, 28 times greater than those of the dispersed VSMCs of SHR and WKY rats, respectively. The $R_{\text {input }}, G_{\text {input' }}$ ' $C_{\text {input }}$ and $\tau$ values of the dispersed VSMCs of SHR rats were the same of the dispersed VSMCs of WKY rats. These results suggested a tighter coupling in the recording circuit in RIA of SHR compared to that of WKY rats, further supporting the tighter electrical coupling among VSMCs in RIA of SHR.

Vasoconstrictive response to vasoconstrictors of RIAs of SHR and WKY rats

To test the vasoconstrictive responses to KCl or PE, RIAs of SHR and WKY rats were stimulated with $\mathrm{KCl}$ (from 10 to $100 \mathrm{mM}$ ) or PE (from 0.1 to $30 \mu \mathrm{M}$ ). The myographic measurement showed that the vasoconstrictive responses of RIA to either $\mathrm{KCl}$ or PE were greater in SHR than that of WKY rats (Figure 3). The $\mathrm{EC}_{50}$ value of PE stimulation was significantly smaller in SHR $\left(\mathrm{EC}_{50}=0.37 \mu \mathrm{M}\right)$ than that in WKY rats $\left(\mathrm{EC}_{50}=0.49 \mu \mathrm{M}\right)(\mathrm{p}<0.05$, $\mathrm{n}=10$ /group), but the $\mathrm{EC}_{50}$ value of $\mathrm{KCl}$ stimulation was not significantly different between SHR $\left(\mathrm{EC}_{50}=31.3 \mu \mathrm{M}\right)$ and $\mathrm{WKY}$ rats $\left(\mathrm{EC}_{50}=38.1 \mu \mathrm{M}\right)(\mathrm{p}>0.05, \mathrm{n}=10 /$ group$)$.

Pre-treated RIA with gap junction inhibitor $18 \beta$-GA for 20 min inhibited the KCl- or PE- 


\section{Kidney \\ Blood Pressure Research}

Kidney Blood Press Res 2015;40:52-65

DOI: 10.1159/000368482

Published onlıne: Fedruary 20, 2015

C 2015 S. Karger AG, Basel

www.karger.com/kbr

Table 3. Whole cell membrane properties of renal interlobar artery (RIA) vascular smooth muscle cells (VSMCs) of SHR and WKY rats at 12 weeks of age

\begin{tabular}{|c|c|c|c|}
\hline Membrane property & & $\begin{array}{l}\text { in situ VSMCs } \\
(\mathrm{n}=8)\end{array}$ & $\begin{array}{l}\text { dispersed } \\
\text { VSMCs } \\
(n=10)\end{array}$ \\
\hline \multirow{4}{*}{$W K Y$} & $R_{\text {input }}(\mathrm{M} \Omega)^{\mathrm{a}}$ & $352 \pm 79^{* *}$ & $2865 \pm 229$ \\
\hline & $G_{\text {input }}(\mathrm{nS})^{\mathrm{a}}$ & $3.37 \pm 0.98^{*}$ & $0.37 \pm 0.04$ \\
\hline & $C_{\text {input }}(\mathrm{pF})^{\mathrm{b}}$ & $168 \pm 26^{*}$ & $9.7 \pm 0.8$ \\
\hline & $\tau(\mathrm{ms})^{\mathrm{b}}$ & $5.5 \pm 0.6^{* *}$ & $0.35 \pm 0.03$ \\
\hline \multirow{4}{*}{$S H R$} & $R_{\text {input }}(\mathrm{M} \Omega)^{\mathrm{a}}$ & $97 \pm 17^{* * \#}$ & $2713 \pm 207$ \\
\hline & $G_{\text {input }}(\mathrm{nS})^{\mathrm{a}}$ & $7.9 \pm 1.1^{* * \#}$ & $0.39 \pm 0.04$ \\
\hline & $C_{\text {input }}(\mathrm{pF})^{\mathrm{b}}$ & $369 \pm 61^{* * \#}$ & $11.32 \pm 0.62$ \\
\hline & $\tau(\mathrm{ms})^{\mathrm{b}}$ & $15.4 \pm 0.5^{\text {**\#\# }}$ & $0.37 \pm 0.07$ \\
\hline \multicolumn{4}{|c|}{$\begin{array}{l}\text { Results are means } \pm \text { SEM. } * p<0.05 \text { and }{ }^{* *} p<0.01 \text {, compare to } \\
\text { dispersed VSMCs. \#p<0.05 and \#\# } \mathrm{p}<0.05 \text {, compared to WKY. } \\
\text { a Measured from }-60 \text { and }-40 \mathrm{mV} \text {. b Measured from }-40 \text { to }-100 \mathrm{mV}\end{array}$} \\
\hline
\end{tabular}
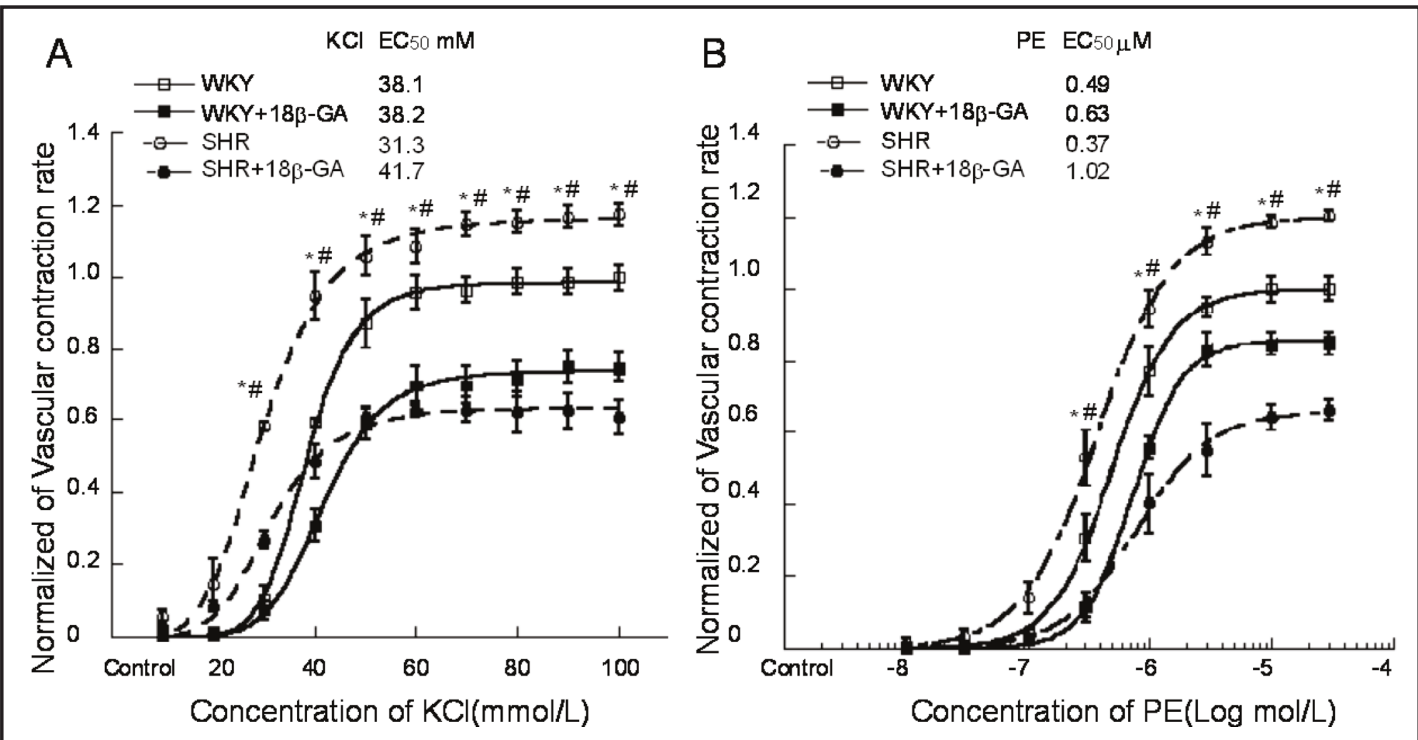

Fig. 3. Effects of gap junction inhibitor $18 \beta$-glycyrrhetintic acid (18ß-GA) on vasoconstriction induced by A) $\mathrm{KCl}$ or $\mathrm{B}$ ) phenylephrine (PE) of renal interlobar artery (RIA) of 12-wk old SHR and WKY rats. The inhibitory effects of $18 \beta-\mathrm{GA}$ inhibitory on $\mathrm{KCl}$ and PE-induced vasoconstriction were greater in SHR. The level of contraction was normalized by value of WKY rats as 1 . Results are means \pm SEM, $n=10$ RIA segments/group. " $\mathrm{p}<0.05$, compared to respective WKY groups; \# $\mathrm{p}<0.05$, effects of $18 \beta-G A$ between SHR and WKY rats.

induced vasoconstriction and right shifted the concentration-dependent responsive curves. The inhibitory effects of $18 \beta$-GA on KCl- or PE-induced vasoconstriction were greater in SHR than that in WKY rats (Figure 3). After $18 \beta$-GA treatment, the $\mathrm{EC}_{50}$ value of PE stimulation was significantly greater in SHR $\left(\mathrm{EC}_{50}=1.02 \mu \mathrm{M}\right)$ than that in $\mathrm{WKY}$ rats $\left(\mathrm{EC}_{50}=0.63 \mu \mathrm{M}\right)(\mathrm{p}<0.05$, $\mathrm{n}=10$ /group), but the $\mathrm{EC}_{50}$ value of $\mathrm{KCl}$ stimulation was not significantly different between $\operatorname{SHR}\left(\mathrm{EC}_{50}=41.7 \mu \mathrm{M}\right)$ and $\mathrm{WKY}$ rats $\left(\mathrm{EC}_{50}=38.2 \mu \mathrm{M}\right)(\mathrm{p}>0.05, \mathrm{n}=10 /$ group$)$.

Age-dependent vasoconstrictive responses to KCl or PE in SHR and WKY rats

We also measured the vasoconstrictive responses to KCl or PE in RIAs of SHR and WKY rats at different age. Dose-response to $\mathrm{KCl}$ (from 10 to $100 \mathrm{mM}$ ) or PE (from 0.1 to $30 \mu \mathrm{M}$ ) stimulation elicited concentration-dependent contraction in the RIA of SHR and WKY rats 


\section{Kidney \\ Blood Pressure \\ Research}

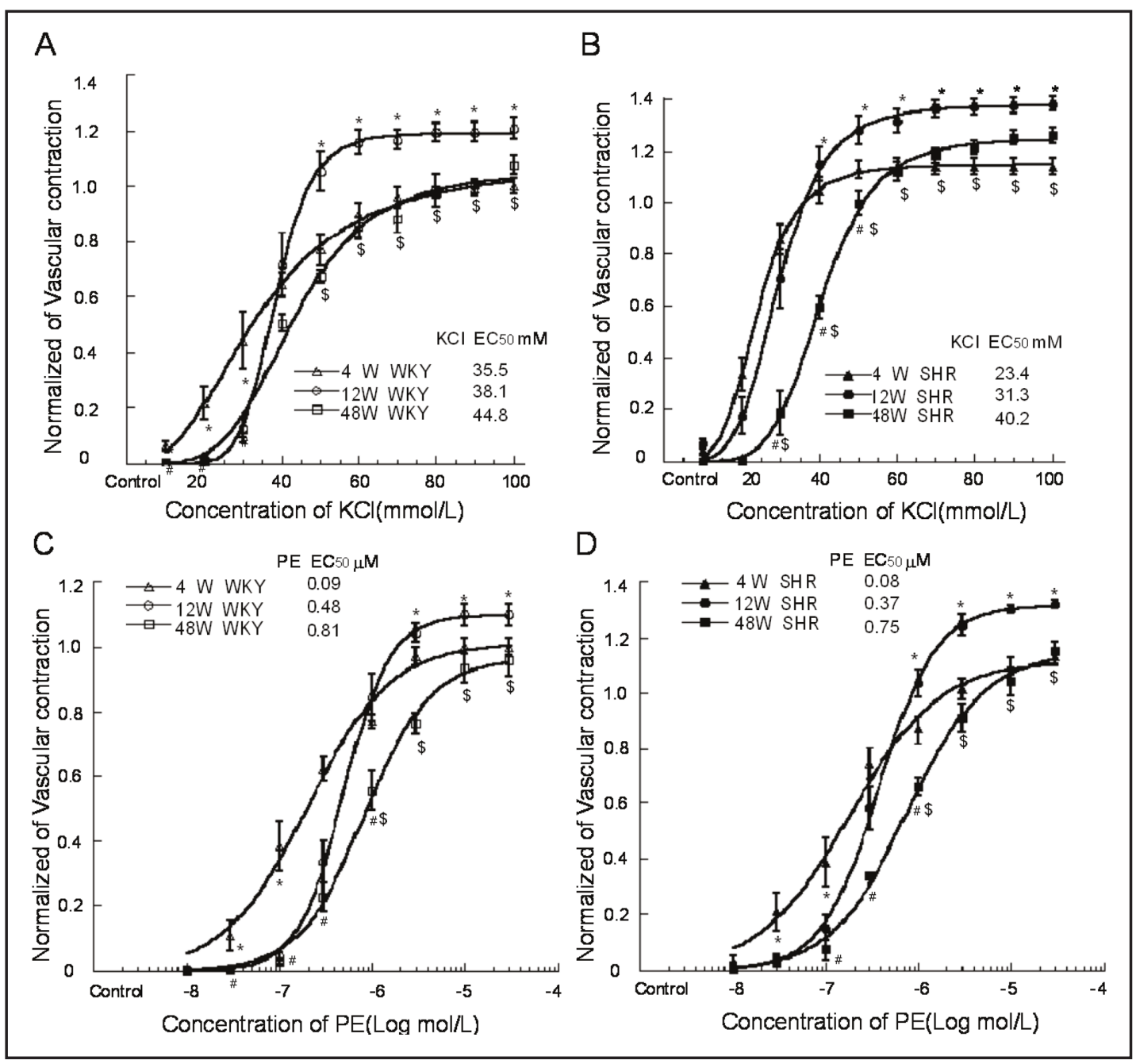

Fig. 4. The KCl- or PE-induced vasoconstriction of renal interlobar artery (RIA) of SHR (A and C) and WKY (B and D) rats at different age, The level of contraction was normalized by the value of respective 4-wk group as 1 . Results are means \pm SEM, $n=10$ RIA segments/group. ${ }^{*} \mathrm{p}<0.05$, comparison between 4 -wk and 12 -wk groups; " $\mathrm{p}<0.05$, comparison between 4 -wk and 48-wk groups; $\$ \mathrm{p}<0.05$, comparison between 12 -wk and 48-wk groups.

at different ages (Figure 4). The vasoconstrictive responses to $\mathrm{KCl}$ or PE were significant different at 4, 12 and 48 weeks of age in both SHR and WKY rats. At 12-wk of age, the KClor PE-stimulated contraction of RIAs was greater than that at 4- and 48-wk of age in both WKY and SHR ( $\mathrm{p}<0.05, \mathrm{n}=10 /$ group). The KCl- and PE-stimulated contraction was the same between 4- and 48-wk of age in both WKY and SHR rats. The peak constrictive responses of RIAs to KCl or PE were significantly greater in SHR compared to those in age-matched WKY rats ( $\mathrm{p}<0.05, \mathrm{n}=10 /$ group).

\section{Expression of CX 45 in RIAs of SHR and WKY rats at different age}

Western blot analysis showed that the expression of Cx45 in RIA was significantly different at different age. Cx45 expression was significantly increased from 4 to 12 weeks and then decreased from 12 to 48 wks of age (Figure 5). RIAs of SHR had higher Cx 45 protein levels than that in WKY rats at all ages studied. 


\section{Kidney \\ Blood Pressure Research}

Kidney Blood Press Res 2015;40:52-65

\begin{tabular}{l|l}
\hline DOI: 10.1159/000368482 & (c) 2015 S. Karger AG, Basel
\end{tabular}

Published onirne: February 20, 2015

www.karger.com/kbr
Discussion

Hypertension is a major risk factor for the development of cardiovascular disease and chronic renal disease [33]. Majority of hypertensive cases are classified as essential or primary hypertension. Essential hypertension is considered to be originated from the interaction between genetic and environmental factors, and is characterized by an increase in blood pressure together with peripheral vascular resistance [33, 34]. Both human and hypertensive animal models are associated with abnormal changes in remodeling of vascular wall and vascular activity [34]. The changes in vascular structure result from hypertrophy or a rearrangement of the smooth muscle layers, which are associated with reducing in the production of vasodilatory factors [34]. Recent studies demonstrate that gap junctions among VSMCs can affect vascular tone by regulate vasomotor activity, and play a abnormal Cxs expression are associated with the development of hypertension [6]. Deletion of the $\mathrm{Cx} 40$ or the $\mathrm{Cx} 45$ genes or altered Cxs expression in mice results in hypertension and hyperreninemia [15]. Besides the effects on vasoconstriction, high expression of Cx45 in ECs and VSMCs is required for normal vascular development during embryogenesis [35]. Global knockout of Cx45 in mice causes vascular malformations and is embryonic lethal [36]. Animals with $\mathrm{Cx} 45$-deficiency fail to form a smooth muscle layer surrounding the artery [16]. These findings demonstrated the $\mathrm{Cx} 45$-dependent gap junctional coupling among vascular cells are essential for maturation of blood vessels. Since gap junctions play a critical role in the propagation of vasoconstriction $[16,34]$, in this study, we investigate the effect of changes in gap junction protein expression and properties of gap junction in VSMCs of RIAs on the development of hypertension in SHRs.

The principal findings of our study are summarized as: 1) the membrane properties of VSMCs of RIA were significantly difference between SHRs and WKY rats, the membrane $C_{\text {input }}$ and $G_{\text {input }}$ were increased and $R_{\text {input }}$ was decreased in SHRs; 2 ) compare to WKY rats, the vasoconstrictive responses of RIA by KCl and PE were significantly greater in SHRs, 18ß-GA treatment inhibited the vasoconstrictive response to $\mathrm{KCl}$ and $\mathrm{PE}$, and the inhibitory effect of 18ß-GA was greater in SHRs than in WKY rats; 3) the age-dependent vasoconstrictive responses to KCl and PE was greater in SHRs than in WKY rats. In both SHR and WKY rats, 12-wk old animals had the strongest responses to $\mathrm{KCl}$ or PE stimulation; and 4) a significant up-regulation of $\mathrm{Cx} 45$ protein expression was observed in 12-wk-old SHR and WKY rats compared to that in 4- and 48-wk-old rats. The expression of $\mathrm{Cx} 45$ protein levels in RIA of SHR was significantly higher than that of WKY rats. These findings suggest that enhanced 


\section{Kidney Blood Pressure Research}

Kidney Blood Press Res 2015;40:52-65

\begin{tabular}{l|l}
\hline DOI: 10.1159/000368482 & (c) 2015 S. Karger AG, Basel
\end{tabular}

Published onine: Fedruary 20, 2015

www.karger.com/kbr

expression of Cx45 and gap junction communication among VSMCs in RIA of SHR may contribute the development of hypertension in SHR.

Gap junctions regulates vasomotor tone and vasomotor activity [21,37]. When there is local stimulation of small arteries or arterioles, the gap junctions can spread the contractive signals along the vessels by several millimeters $[22,23]$. Vascular wall is mainly made up of VSMCs and endothelial cells, they work together to coordinate contraction of blood vessels. The gap junction could ensure the signal transmission rate, to make the blood vessels quickly and unified contraction or relaxation. When the body is in pathological states or during aging, the structure, function and expression of gap junction will change, which will cause the synchronization vasomotor activity obstacles of the vascular wall cells [38].

In the current study, whole-cell recordings of VSMCs still embedded in RIA were used to measure gap junction communication. This novel technique allowed us to determine the function of gap junctions among VSMCs under a more physiologically condition (compared to dispersed VSMCs) $[39,40]$. Table 3 showed that the $G_{\text {input }}$ and $C_{\text {input }}$ of in-situ VSMCs were greater than those of dispersed VSMCs, suggesting a tight electrical coupling among VSMCs in the recording circuit in vivo. Further, the $G_{\text {input }}$ and $C_{\text {input }}$ were greater in SHR versus WKY rats, suggesting a tighter electrical coupling among VSMCs in RIA of SHR versus WKY rats, supporting the results in Figure 2. The coupling between various cell types, the number of junctional channels and the channel openning probability are modulated by multiple mechanisms, including the synthesis of Cxs, the intracellular trafficking of Cx proteins, the assembly of Cxs into plasma membrane, and the turnover rate of Cx proteins [10]. Recent study has shown that the coupling between nephrons is increased in SHR, suggesting that changes in nephron coupling may be accosiated with the development of hypertension [41]. The enhanced coupling between VSMCs and ECs has also been observed in SHR [23]. The greater VSMC-EC coupling has been assumed to be a compensatory mechanism to maintain blood pressure regulation through the endothelium-derived hyperpolarizing factor (EDHF) signaling in this hypertensive model [16]. Thus, increased electrical coupling in RIA artery of SHR may be accompanied by tighter VSMC-EC gap junctions that formed by $\mathrm{Cx} 40$ and $\mathrm{Cx} 43$.

The time course of the current transients during the voltage stepping fit well with a single-term exponential function in the dispersed VSMCs, however, fit poorly with a singleterm exponential function in the in-situ VSMCs, indicating multiple membrane sources in the circuit or an electrical coupling of multiple cells in-situ. Increased electrical coupling among VSMCs of SHR resulted in longitudinal electrical conduction accompanied by membrane potential changes, and produces more uniform contractile responses. Change in membrane potential results in the opening of voltage-sensitive $\mathrm{Ca}^{2+}$ channels, and this in turn enhanced vasomotor tone over vessel segments within several millimeters in length [16]. ATP induces $\mathrm{Ca}^{2+}$ mobilization in neighboring cells via hemichannels, which may stimulate purinergic receptors on cells and give rise to a propagated $\mathrm{Ca}^{2+}$ wave [6]. Therefore, increased expression of Cx45 may lead to enhanced $\mathrm{Ca}^{2+}$ wave and secretion of ATP in RIAs of SHR, thus results in increasing in vascular tone and hypertension. Hypertension can lead to hypertrophy of VSMCs [42], and the $C_{\text {input }}$ of a cell is positively correlated with the cell size. Although the $C_{\text {input }}$ of in-situ VSMCs of SHR was much higher than that of WKY rats, the $C_{\text {input }}$ of a single VSMC of SHR was the same as that of a single VSMC of WKY rat, suggesting that the hypertrophy of VSMCs had little effect on gap junction communication.

RIAs of both SHR and WKY rats showed a dose-dependent vasoconstrictive response to $\mathrm{KCl}$ or PE stimulation. The contractive response stimulated by $\mathrm{KCl}$ and $\mathrm{PE}$ was greater in SHR than in WKY rats. Previous studies have shown that there are differences in vascular function between SHR and WKY rats [31]. KCl-stimulated vascular contraction was enhanced in preglomerular vessels of SHR compared to normotensive rats [43]. Early studies in our laboratory have demonstrated contractive response of mesenteric artery was significantly increased in SHR compared to that in WKY rats [31]. Combined with the results of the wholecell patch-clamp measurement, our current findings suggest that the increased gap junction communication was involved in the greater vasoconstrictive response and the development 


\section{Kidney Blood Pressure Research}

Kidney Blood Press Res 2015;40:52-65

\begin{tabular}{l|l}
\hline DOI: $10.1159 / 000368482$ & (C) 2015 S. Karger AG, Basel
\end{tabular}

Published oninne: Fedruary 20, 2015

www.karger.com/kbr

of hypertension in SHR. $18 \beta$-GA also can interfere with $\mathrm{Ca}^{2+}$ wave propagation [6], which is consistent with the inhibitory effect of $18 \beta$-GA on the contractive response stimulated by $\mathrm{KCl}$ and PE was greater in SHRs than in WKY rats. It has been shown that pretreatment with $18 \beta$ GA has hepatoprotective effects through attenuation of oxidative stress, inflammation and hyper-proliferation, which imply that $18 \beta$-GA may have therapeutic effect on hypertension by anti-inflammation and by inhibition of VSMC hyper-proliferation [44].

Many experiments have demonstrated that gap junction proteins were expressed in VSMCs in various vascular beds [45-47]. In this study, we showed that Cx45 protein was expressed in RIAs of SHR and WKY rats. The levels of Cx45 were significantly higher in SHR than in WKY rats. Xing Li and J. Marc Simard found that Cx45 expression is increased in cerebral arterial VSMCs of SHR $[17,48,49]$. In DOCA-salt, Goldblatt 2 kidney-1 clip (2K1C) and NO synthase inhibition models of hypertension, the blood pressure, increased angiotensin II and reduced NO are associated with the change in vascular Cx protein levels [50]. The function and turnover of gap junction is regulated by its interaction with many proteins, including protein kinases and phosphatases [51]. Interaction among Cxs may triggered alteration of the expression of themselves [51]. In this study, the increased Cx45 expression in RIA of SHR may result from reduced phosphorylation of $\mathrm{Cx} 45$ and altered interaction between $\mathrm{Cx} 45$ and Cx-associated proteins such as ZO-1 [12], which could prolonged the turnover rate of $\mathrm{Cx} 45$ [11], thus resulted in changes in activity of other Cxs in renal vasculature, and enhanced vasoconstriction and electrical coupling in RIA of SHR.

Our study indicated that propagated vasoconstriction in response to local application of $\mathrm{KCl}$ was inhibited in mesenteric arterioles of Cx37 knockout mice [6]. Study of Schmidt et al. demonstrated that the amplitude of $\mathrm{K}^{+}$initiated endothelium-independent vasoconstriction declines in $\mathrm{Cx} 45$ deficient mice [32]. In the current study, we found that there are agedependent changes in vasoconstrictive responses to $\mathrm{KCl}$ or PE in SHR and WKY rats. Higher blood pressure was associated with increase in expression of Cx45 in RIAs of SHR at 12-wk of age compared to that of WKY rats at the same age, which might contribute to greater vasoconstriction when RIAs were stimulated by $\mathrm{KCl}$ or $\mathrm{PE}$. These results suggested that $\mathrm{Cxs}$ are dispensable for the conduction of vasomotor responses and regulation of blood pressure. To date, few data are available on the vasoconstrictive effect of $\mathrm{Cx} 45$ in humans. A recent study shows that there was a remarkable resemblance of the distribution of $\mathrm{Cx} 37, \mathrm{Cx} 40, \mathrm{Cx} 43$ and $\mathrm{Cx} 45$ between the human and rodent kidneys [7,13], suggesting that the expression of vascular Cxs in kidney may be rather conserved among the mammalian species [7]. In future studies, we will investigate whether this phenomenon is correlated with the expression and function of gap junction.

\section{Conclusion}

Our current study demonstrated that the hypertension-induced elevation of $\mathrm{Cx} 45$ may affect communication between VSMCs and coupling between VSMCs and ECs, which resulted in enhancement of vasoconstrictive response in renal artery and contributed to the development of hypertension.

\section{Disclosure Statement}

The authors of this manuscript state that they do not have any conflict of interests and nothing to disclose. 


\section{Kidney \\ Blood Pressure Research}

Kidney Blood Press Res 2015;40:52-65

\begin{tabular}{l|l}
\hline DOI: $10.1159 / 000368482$ & (C) 2015 S. Karger AG, Basel
\end{tabular}

Published ontrne: Fedruary 20, 2015

www.karger.com/kbr

\section{Acknowledgement}

This work was supported by the National Basic Research Program of China (2012CB52660000 to Jun-Qiang Si) and the National Natural Science Foundation of China (31260247 to Ke-Tao Ma, 31100829 to Xin-Zhi Li and 81000411 to Li Li).

\section{References}

1 Rettig R, Stauss H, Folberth C, Ganten D, Waldherr B, Unger T: Hypertension transmitted by kidneys from stroke-prone spontaneously hypertensive rats. Am J Physiol 1989;257:F197-203.

-2 Patschan O, Kuttler B, Heemann U, Uber A, Rettig R: Kidneys from normotensive donors lower blood pressure in young transplanted spontaneously hypertensive rats. Am J Physiol 1997;273:R175-180.

-3 Brisset AC, Isakson BE, Kwak BR: Connexins in vascular physiology and pathology. Antioxid Redox Signal 2009;11:267-282.

-4 Kurtz A: Renal connexins and blood pressure. Biochim Biophys Acta 2012;1818:1903-1908.

5 Wagner C: Function of connexins in the renal circulation. Kidney Int 2008;73:547-555.

6 Hanner F, Sorensen CM, Holstein-Rathlou NH, Peti-Peterdi J: Connexins and the kidney. Am J Physiol Regul Integr Comp Physiol 2010;298:R1143-1155.

7 Kurtz L, Madsen K, Kurt B, Jensen BL, Walter S, Banas B, Wagner C, Kurtz A: High-level connexin expression in the human juxtaglomerular apparatus. Nephron Physiol 2010;116:p1-8.

8 Rackauskas M, Verselis VK, Bukauskas FF: Permeability of homotypic and heterotypic gap junction channels formed of cardiac connexins mCx30.2, Cx40, Cx43, and Cx45. Am J Physiol Heart Circ Physiol 2007;293:H1729-1736.

-9 Brücher BL, Jamall IS: Cell-cell communication in the tumor microenvironment, carcinogenesis, and anticancer treatment. Cell Physiol Biochem 2014;34:213-243.

10 Herve JC, Derangeon M, Bahbouhi B, Mesnil M, Sarrouilhe D: The connexin turnover, an important modulating factor of the level of cell-to-cell junctional communication: comparison with other integral membrane proteins. J Membr Biol 2007;217:21-33.

11 Giepmans BN: Gap junctions and connexin-interacting proteins. Cardiovasc Res 2004;62:233-245.

12 Laing JG, Koval M, Steinberg TH: Association with ZO-1 correlates with plasma membrane partitioning in truncated connexin45 mutants. J Membr Biol 2005;207:45-53.

13 Takenaka T, Inoue T, Kanno Y, Okada H, Meaney KR, Hill CE, Suzuki H: Expression and role of connexins in the rat renal vasculature. Kidney Int 2008;73:415-422.

14 Kurtz L, Gerl M, Kriz W, Wagner C, Kurtz A: Replacement of connexin 40 by connexin 45 causes ectopic localization of renin-producing cells in the kidney but maintains in vivo control of renin gene expression. Am J Physiol Renal Physiol 2009;297:F403-409.

15 Schweda F, Kurtz L, de Wit C, Janssen-Bienhold U, Kurtz A, Wagner C: Substitution of connexin40 with connexin45 prevents hyperreninemia and attenuates hypertension. Kidney Int 2009;75:482-489.

16 Figueroa XF, Duling BR: Gap junctions in the control of vascular function. Antioxid Redox Signal 2009;11:251-266.

17 Figueroa XF, Isakson BE, Duling BR: Vascular gap junctions in hypertension. Hypertension 2006;48:804811.

18 Muraki K, Watanabe M, Imaizumi Y: Nifedipine and nisoldipine modulate membrane potential of vascular endothelium via a myo-endothelial pathway. Life Sci 2000;67:3163-3170.

19 Figueroa XF, Paul DL, Simon AM, Goodenough DA, Day KH, Damon DN, Duling BR: Central role of connexin 40 in the propagation of electrically activated vasodilation in mouse cremasteric arterioles in vivo. Circ Res 2003;92:793-800.

20 Looft-Wilson RC, Payne GW, Segal SS: Connexin expression and conducted vasodilation along arteriolar endothelium in mouse skeletal muscle. J Appl Physiol (1985) 2004;97:1152-1158. 


\section{Kidney \\ Blood Pressure Research}

Kidney Blood Press Res 2015;40:52-65

\begin{tabular}{l|l}
\hline DOI: $10.1159 / 000368482$ & C 2015 S. Karger AG, Basel
\end{tabular}

Publisned oninne: February 20, 2015

www.karger.com/kbr

-21 Segal SS, Duling BR: Propagation of vasodilation in resistance vessels of the hamster: development and review of a working hypothesis. Circ Res 1987;61:II20-25.

-22 Gustafsson F, Holstein-Rathlou NH: Angiotensin II modulates conducted vasoconstriction to norepinephrine and local electrical stimulation in rat mesenteric arterioles. Cardiovasc Res 1999;44:176184.

-23 Wagner AJ, Holstein-Rathlou NH, Marsh DJ: Internephron coupling by conducted vasomotor responses in normotensive and spontaneously hypertensive rats. Am J Physiol 1997;272:F372-379.

24 Dilley JR, Arendshorst WJ: Enhanced tubuloglomerular feedback activity in rats developing spontaneous hypertension. Am J Physiol 1984;247:F672-679.

-25 Holstein-Rathlou NH, Leyssac PP: TGF-mediated oscillations in the proximal intratubular pressure: differences between spontaneously hypertensive rats and Wistar-Kyoto rats. Acta Physiol Scand 1986;126:333-339.

26 Persson AE, Boberg U: Renal abnormalities in experimental models of hypertension: the SHR versus the Milan HR. J Cardiovasc Pharmacol 1988;12:S27-35.

-27 Dilley JR, Stier CT, Jr., Arendshorst WJ: Abnormalities in glomerular function in rats developing spontaneous hypertension. Am J Physiol 1984;246:F12-20.

28 Chen YM, Yip KP, Marsh DJ, Holstein-Rathlou NH: Magnitude of TGF-initiated nephron-nephron interactions is increased in SHR. Am J Physiol 1995;269:F198-204.

29 Li XZ, Ma KT, Guan BC, Li L, Zhao L, Zhang ZS, Si JQ Jiang ZG: Fenamates block gap junction coupling and potentiate BKCa channels in guinea pig arteriolar cells. Eur J Pharmacol 2013;703:74-82.

30 Li L, Wang R, Ma KT, Li XZ, Zhang CL, Liu WD, Zhao L, Si JQ: Differential effect of calcium-activated potassium and chloride channels on rat basilar artery vasomotion. J Huazhong Univ Sci Technolog Med Sci 2014;34:482-490.

-31 Ma KT, Li XZ, Li L, Jiang XW, Chen XY, Liu WD, Zhao L, Zhang ZS, Si JQ: Role of gap junctions in the contractile response to agonists in the mesenteric artery of spontaneously hypertensive rats. Hypertens Res 2014;37:110-115.

-32 Schmidt VJ, Jobs A, von Maltzahn J, Worsdorfer P, Willecke K, de Wit C: Connexin45 is expressed in vascular smooth muscle but its function remains elusive. PLoS One 2014;7:e42287.

33 Singh MV, Chapleau MW, Harwani SC, Abboud FM: The immune system and hypertension. Immunol Res 2014;59:243-253.

34 Rummery NM, Hill CE: Vascular gap junctions and implications for hypertension. Clin Exp Pharmacol Physiol 2004;31:659-667.

35 Fang JS, Dai C, Kurjiaka DT, Burt JM, Hirschi KK: Connexin45 regulates endothelial-induced mesenchymal cell differentiation toward a mural cell phenotype. Arterioscler Thromb Vasc Biol 2013;33:362-368.

-36 Kruger O, Plum A, Kim JS, Winterhager E, Maxeiner S, Hallas G, Kirchhoff S, Traub O, Lamers WH, Willecke K: Defective vascular development in connexin 45-deficient mice. Development 2000;127:4179-4193.

-37 Looft-Wilson RC, Haug SJ, Neufer PD, Segal SS: Independence of connexin expression and vasomotor conduction from sympathetic innervation in hamster feed arteries. Microcirculation 2004;11:397-408.

-38 Azzam EI, de Toledo SM, Little JB: Direct evidence for the participation of gap junction-mediated intercellular communication in the transmission of damage signals from alpha -particle irradiated to nonirradiated cells. Proc Natl Acad Sci USA 2001;98:473-478.

-39 Guan BC, Si JQ Jiang ZG: Blockade of gap junction coupling by glycyrrhetinic acids in guinea pig cochlear artery: a whole-cell voltage- and current-clamp study. Br J Pharmacol 2007;151:1049-1060.

40 Ma KT, Guan BC, Yang YQ Nuttall AL, Jiang ZG: 2-Aminoethoxydiphenyl borate blocks electrical coupling and inhibits voltage-gated $\mathrm{K}+$ channels in guinea pig arteriole cells. Am J Physiol Heart Circ Physiol 2011;300:H335-346.

41 Arensbak B, Mikkelsen HB, Gustafsson F, Christensen T, Holstein-Rathlou NH: Expression of connexin 37, 40, and 43 mRNA and protein in renal preglomerular arterioles. Histochem Cell Biol 2001;115:479-487.

42 Lacolley P, Regnault V, Nicoletti A, Li Z, Michel JB: The vascular smooth muscle cell in arterial pathology: a cell that can take on multiple roles. Cardiovasc Res 2012;95:194-204.

-43 Yamamoto Y, Fukuta H, Nakahira Y, Suzuki H: Blockade by 18beta-glycyrrhetinic acid of intercellular electrical coupling in guinea-pig arterioles. J Physiol 1998;511:501-508. 


\section{Kidney \\ Blood Pressure Research}

44 Hasan S, Khan R, Ali N, Khan A, Rehman M, Tahir M, Lateef A, Nafees S, Mehdi S, Rashid S, Shahid A, Sultana S: 18-beta Glycyrrhetinic acid alleviates 2-acetylaminofluorene-induced hepatotoxicity in Wistar rats: Role in hyperproliferation, inflammation and oxidative stress. Hum Exp Toxicol 2014, in press.

45 de Wit C, Griffith TM: Connexins and gap junctions in the EDHF phenomenon and conducted vasomotor responses. Pflugers Arch 2010;459:897-914.

-46 Yamamoto Y, Klemm MF, Edwards FR, Suzuki H: Intercellular electrical communication among smooth muscle and endothelial cells in guinea-pig mesenteric arterioles. J Physiol 2001;535:181-195.

-47 Yamazaki J, Kitamura K: Intercellular electrical coupling in vascular cells present in rat intact cerebral arterioles. J Vasc Res 2003;40:11-27.

48 McGuire PG, Twietmeyer TA: Aortic endothelial junctions in developing hypertension. Hypertension 1985;7:483-490.

49 Li X, Simard JM: Increase in Cx45 gap junction channels in cerebral smooth muscle cells from SHR. Hypertension 2002;40:940-946.

50 Haefliger JA, Demotz S, Braissant O, Suter E, Waeber B, Nicod P, Meda P: Connexins 40 and 43 are differentially regulated within the kidneys of rats with renovascular hypertension. Kidney Int 2001;60:190201.

51 Figueroa XF, Isakson BE, Duling BR: Connexins: gaps in our knowledge of vascular function. Physiology (Bethesda) 2004;19:277-284. 